\title{
Inhibitory effect of various cytostatics and cycloheximide on acute experimental pancreatitis in rats
}

\author{
L. KORBOVÁ, J. KOHOUT, F. MALIŠ, V. BALAŠ, J. ČíŽKOVÁ, J. MAREK, \\ AND A. ČIHÁK \\ From the Department of Pathological Physiology, 1st Department of Surgery, 2nd Department of \\ Gastroenterological Research, 2nd Department of Pathological Anatomy, Faculty of General Medicine, \\ Charles University, and from Institute of Organic Chemistry and Biochemistry, Czechoslovak Academy \\ of Sciences, Prague, Czechoslovakia
}

SUMMARY Cycloheximide, 5-azacytidine, and 4-methoxybenzoyl- $\beta$-bromoacrylate (Cytembena) block the development of experimental acute pancreatitis in rats when mediated by the administration of $5 \%$ bile solution into the pancreas in vivo. Six hours after drug treatment the pathological changes, evaluated macroscopically or using histological sections of the pancreas, were significantly decreased. The drugs affected the amount of abdominal fluid and lowered its lipase and amylase activity. The known inhibitory mechanism of the active drugs and the possible advantage of cycloheximide for clinical use are briefly mentioned.

Acute pancreatitis is accompanied by haemorrhagic and necrotic changes (Carey, 1973; Palmer, 1975). The main lesion is necrosis of acinar cells and the clinical course of the illness depends on how much of the exocrine part of the pancreas is destroyed (Edlund, 1970). The relation between the pancreas and the products of its secretion, the phenomenon of autodigestion, and all the features of acute pancreatitis are continually being studied (Beck et al., 1965; Creutzfeldt and Schmidt, 1970; Becker, 1973; White and Allan, 1974). In the course of development of acute pancreatitis different acinar enzymes are activated. At the forefront of today's chemotherapy of the disease are drugs which block the activity of pancreatic enzymes and their autodigestive action on the organism. At present the curative action of trypsin inhibitors-for example, Trasylol, Antilysin-is well established (Beck et al., 1965; Nugent and Atendido, 1965; Baden et al., 1969; Malis et al., 1972).

Pancreatic tissue is characterised by a high rate of synthesis of proteins and nucleic acids (Walther et al., 1974; Cohen and Kulka, 1974). It is suggested that drugs interfering with the synthesis of these macromolecules affect the formation of pancreatic enzymes. Similar drugs are often used as cytostatics.

Received for publication 6 April 1977
Recently, Johnson et al. (1973) observed that 5fluorouracil favourably affects the course of experimental pancreatitis in dogs. In our earlier study (Korbová et al., 1974) we found that 5-azacytidine affects gastric secretion in rats as well as the incidence of experimental gastric ulcers and depresses the secretion of enzymes from the pancreas. Similarly, 5-bromo-2'-deoxyuridine was found to exert a selective inhibitory effect on embryonic rat pancreas (Walther et al., 1974). Consequently, we decided to investigate the effect of certain drugs that interfere with the synthesis of nucleic acids and proteins in the course of acute experimental pancreatitis in rats.

\section{Methods}

Several methods of producing acute experimental pancreatitis are known-for instance, perfusing the bile ducts (Elliott et al., 1958; Beck et al., 1964), interstitially administering different compounds (Keith et al., 1958; Waterman et al., 1969), or by the action of various stimuli or inducers (Bawnik et al., 1974; Schiller et al., 1974; Backwinkel et al., 1975; Lombardi et al., 1975). In the present study 90 male rats (Wistar, 250-300 g) were kept on a standard diet and separated into several groups. Laparotomy was carried out under mild ether narcosis and $0.6 \mathrm{ml} 5 \%$ bile solution was administered interstitially into the 
pancreas (Keith et al., 1958). After six hours of treatment the animals were killed by cervical dislocation and the volume of abdominal fluid was measured. The macroscopic changes (necrosis) in the pancreas and in the abdominal cavity were evaluated as shown in Table 1. In this classification the highest number of points was allocated to haemorrhagic and necrotic changes, followed by necrosis of the pancreas, and oedema and necrosis in the abdominal cavity.

After killing the animals the pancreas was removed and kept on solid carbon dioxide at $-30^{\circ} \mathrm{C}$. Another group of animals was used for the histological examination. The pancreas was fixed in neutral formaldehyde and sections of the tissue were stained with haematoxylin and eosin. Collected blood was immediately centrifuged and serum as well as abdominal fluid was kept at $-18^{\circ} \mathrm{C}$.

Trypsin and chymotrypsin were measured after homogenisation of the pancreas in aequeous $0.5 \% \mathrm{NaCl}$ containing $0.05 \% \mathrm{CaCl}_{2}$ (pH 5.2) in the ratio of $1: 4(\mathrm{w}: \mathrm{v})$ under cooling in a glass homogeniser. Proteinase activity was measured photometrically after activation by enterokinase (Organon) or by trypsin (Spofa). For trypsin estimation synthetically prepared $\mathrm{N}$ - $\alpha$-tosyl-L-arginine-pnitroanilide was used as the substrate (Mališ et al., 1974), for chymotrypsin $\mathrm{N}$ - $\alpha$-succinyl-L-phenylalanine-p-nitroanilide (Suphena). Lipolytic activity was assayed photometrically according to Raderecht (1959), amylase was measured according to Teller (1950), and protein content according to Lowry et al. (1951). Enzyme activities are expressed as milligrams of crystalline trypsin and chymotrypsin per gram of protein or in milligrams of reaction products (amylase-reducing sugars, lipase-phenol) per $100 \mathrm{ml}$ of serum. Enzyme activity in the abdominal fluid was expressed as $\mathrm{mg}$ per $\mathrm{ml}$, or per total volume of the fluid. The statistical significance of the data was evaluated by Student's $t$ test.

5-Azacytidine (Čihák, 1975) (4-amino-1- $\beta$-Dribofuranosyl-1,3,5-triazin-2-one) was prepared in the Institute of Organic Chemistry and Biochemistry in Prague. Cytembena (Slaviková et al., 1971) (sodium cis- $\beta$-4-methoxybenzoyl- $\beta$-bromoacrylate), and Antilysin (natural polypeptid isolated from lung) (Mansfield et al., 1960) were supplied by Spofa, Prague, and cycloheximide (Actidione) was from Calbiochem, Lucerne. The drugs were administered subcutaneously, except for Antilysin, which was injected intraperitoneally, immediately after infiltration of the pancreas by the bile solution.

\section{Results}

All the drugs tested, except Antilysin, caused macro-
Table 1 Classification of necrotic changes in pancreas and abdominal cavity according to macroscopic evaluation

\begin{tabular}{ll}
\hline Changes & $\begin{array}{l}\text { Classification } \\
\text { points }\end{array}$ \\
\hline Pancreas & \\
Oedema & $0-10$ \\
Necrosis & $0-20$ \\
Haemorrhage & $0-30$ \\
Abdominal cavity & $0-5$ \\
Necrosis of mesenterium and intestinal serosa & $0-4$ \\
Necrosis of retroperitoneal fatty tissue & 0 \\
\hline
\end{tabular}

Table 2 Effect of various drugs on extent of necrosis in pancreas and abdominal cavity caused by $5 \%$ bile solution

\begin{tabular}{|c|c|c|c|c|}
\hline \multirow[t]{2}{*}{ Drug } & \multirow{2}{*}{$\begin{array}{l}\text { Rats } \\
\text { (no.) }\end{array}$} & \multirow{2}{*}{$\begin{array}{l}\text { Dose } \\
(m g / k g)\end{array}$} & \multicolumn{2}{|l|}{ Classification } \\
\hline & & & Points $\pm S E$ & $\%$ \\
\hline $\begin{array}{l}\text { Control } \\
\text { Antilysin } \\
\text { Cytembena } \\
\text { 5-Azacytidine } \\
\text { Cycloheximide }\end{array}$ & $\begin{array}{l}25 \\
13 \\
13 \\
13 \\
13\end{array}$ & $\begin{array}{l}100000 \mathrm{KIU} \\
2 \cdot 0 \\
4 \cdot 85 \\
0 \cdot 25\end{array}$ & $\begin{array}{l}45 \cdot 1 \pm 5 \cdot 4^{*} \\
43 \cdot 4 \pm 3 \cdot 1 \\
16 \cdot 3 \pm 2 \cdot 0^{*} \\
17 \cdot 0 \pm 2 \cdot 9^{*} \\
11 \cdot 4 \pm 1 \cdot 3^{*}\end{array}$ & $\begin{array}{l}100 \\
96 \cdot 0 \\
36 \cdot 1 \\
37 \cdot 6 \\
25 \cdot 2\end{array}$ \\
\hline
\end{tabular}

$* \mathrm{P}<0.01$.

scopic changes in the pancreas which were not observed in control animals receiving bile solution only. The most effective drug in the treatment of acute experimental pancreatitis was cycloheximide (Table 2). However, 5-azacytidine and Cytembena also significantly reduced the pathological changes observed in the pancreas. Haemorrhagic and necrotic pancreatitis was observed only exceptionally after the administration of the three drugs. Most of the changes included focal necrosis and oedema. After the administration of cycloheximide very little haemorrhagic necrosis was observed, areas of oedema were smaller, and the appearance of the lower third of the pancreatic tissue was practically normal.

The macroscopic differences are in agreement with the histological observations. After the interstitial administration of a $5 \%$ bile solution the majority of acini in the pancreas of animals not treated with the drugs were necrotic with extensive haemorrhage both in necrotic areas and in the surrounding interstitial tissue; here also there was a mixed inflammatory cell population and considerable oedema (Fig. 1). Administration of Cytembena, 5-azacytidine, and cycloheximide caused necrosis which was not characterised by haemorrhage, and was localised in a narrow strip of the periphery of lobulus with a mixed inflammatory cell population and environmental oedema (Fig. 2). Small haemorrhagic changes 


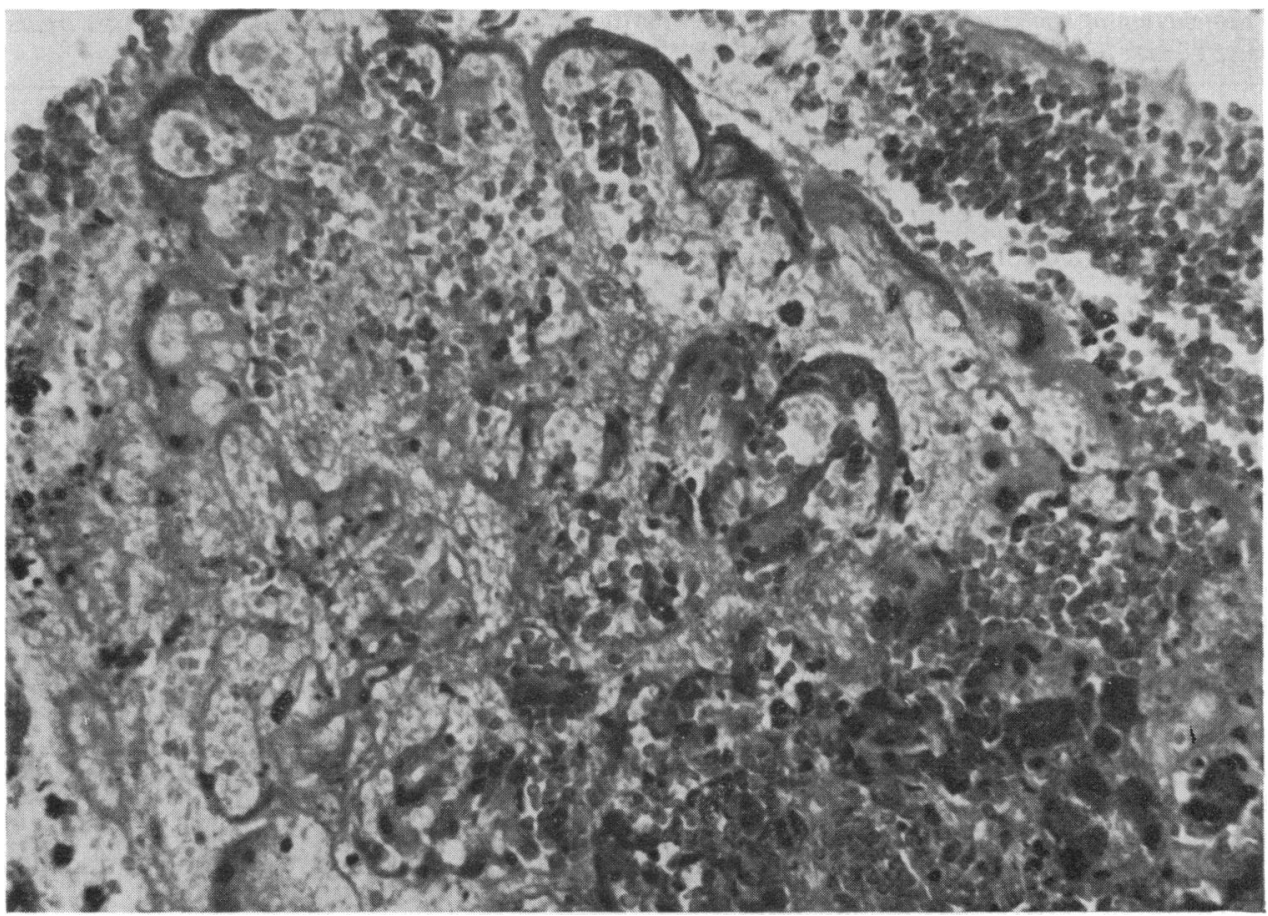

Fig. 1 In untreated animals interstitial administration of $5 \%$ bile solution causes necrosis and extensive haemorrhage in most of the pancreatic acini and in the surrounding tissue. Oedema and inflammatory cells can be seen in the interstitium. $\times 400$.

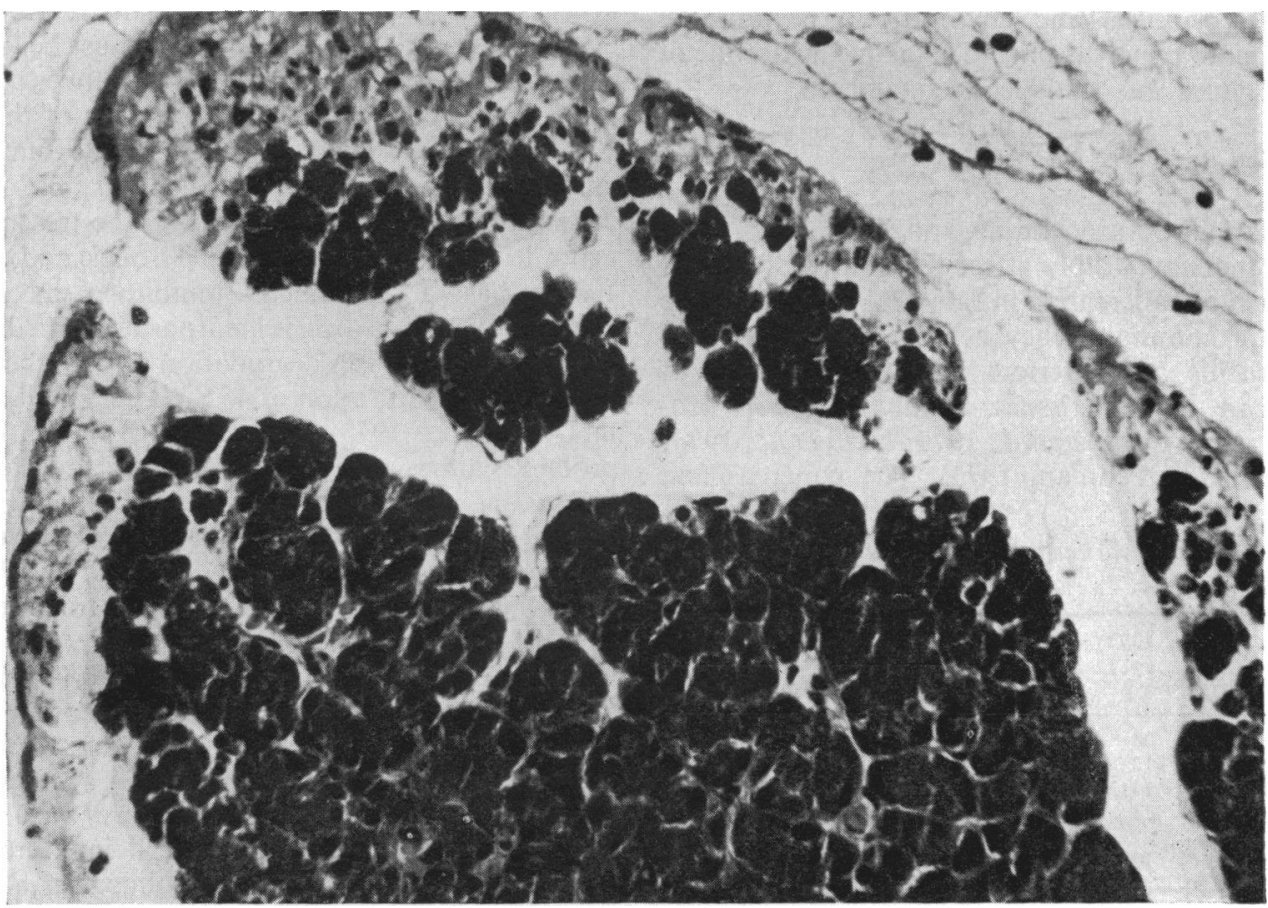

Fig. 2 In animals treated with Cytembena interstitial administration of $5 \%$ bile solution causes oedema, infiltration, and necrosis on the periphery of lobulus only. $\times 400$. 
Table 3 Reduction of haemorrhagic fluid in abdominal cavity and its amylase and lipase activity in rats treated simultaneously with $5 \%$ bile solution and various drugs

\begin{tabular}{|c|c|c|c|c|c|c|c|c|}
\hline \multirow[t]{2}{*}{ Drug } & \multirow{2}{*}{$\begin{array}{l}\text { Rats } \\
\text { (no.) }\end{array}$} & \multirow{2}{*}{$\begin{array}{l}\text { Dose } \\
(m g / k g)\end{array}$} & \multicolumn{2}{|l|}{ Abdominal fluid } & \multicolumn{2}{|l|}{ Amylase } & \multicolumn{2}{|l|}{ Lipase } \\
\hline & & & $(m l \pm S E)$ & $(\%)$ & (Somogyi $U \pm S E$ ) & $(\%)$ & $(m g \pm S E)$ & $(\%)$ \\
\hline Antilysin & 13 & $100000 \mathrm{KIU}$ & $5.00 \pm 0.51$ & 125 & $1769 \cdot 0 \pm 127 \cdot 1$ & 94 & $18 \cdot 5 \pm 2 \cdot 2$ & 115 \\
\hline Cytembena & 13 & $2 \cdot 0$ & $2.95 \pm 0.51$ & 71 & $1349.7 \pm 193.7$ & 70 & $14 \cdot 8 \pm 2 \cdot 1$ & 92 \\
\hline 5-Azacytidine & 13 & $4 \cdot 85$ & $2.68 \pm 0.57 \dagger$ & 67 & $726.8 \pm 183.9 *$ & 39 & $11 \cdot 2 \pm 2.9$ & 70 \\
\hline Cycloheximide & 13 & $0 \cdot 25$ & $2.26 \pm 0.33^{*}$ & 57 & $1205 \cdot 0 \pm 237 \cdot 1^{*}$ & 64 & $11 \cdot 2 \pm 2 \cdot 8$ & 70 \\
\hline
\end{tabular}

${ }^{*} \mathbf{P}<0.01 . \quad+\mathrm{P}<0.05$.

were observed only in $8 \%$ of cases. After Antilysin had been administered histological patterns did not differ from the control sections of the pancreas.

The administration of the tested drugs (with the exception of Antilysin) also lessened the haemorrhagic fluid in the abdominal cavity. The decline in its volume after treatment with 5-azacytidine and cycloheximide was statistically significant. At the same time the level of lipase and amylase activity in the abdominal fluid was decreased (Table 3). The level of trypsinogen and chymotrypsinogen in the pancreas was unchanged, as was the glucose level in serum and abdominal fluid and the serum lipase activity. However, after the administration of 5-azacytidine and cycloheximide the activity of serum amylase was significantly depressed (Table 4). The administration of Antilysin resulted in the lowering of trypsinogen and chymotrypsinogen in the homogenised pancreas only (Table 5). The decline of both enzymes was statistically significant.

\section{Discussion}

Cycloheximide, 5-azacytidine, and Cytembena, compounds that favourably affect the course of experimental acute pancreatitis in rats (Table 2), have one feature in common. They act on the synthesis of nucleic acids and interfere with the synthesis of proteins in different tissues, mainly in rapidly proliferating ones (Veselá et al., 1970; Novi et al., 1973; Reichman and Penman, 1973). The pancreas and

Table 4 Effect of various drugs on serum amylase activity

\begin{tabular}{|c|c|c|c|c|}
\hline \multirow[t]{2}{*}{ Drug } & \multirow{2}{*}{$\begin{array}{l}\text { Rats } \\
\text { (no.) }\end{array}$} & \multirow{2}{*}{$\begin{array}{l}\text { Dose } \\
(m g / k g)\end{array}$} & \multicolumn{2}{|l|}{ Amylase } \\
\hline & & & (Somogyi $U \pm S E$ ) & $(\%)$ \\
\hline $\begin{array}{l}\text { Control } \\
\text { Cytembena } \\
\text { 5-Azacytidine } \\
\text { Cycloheximide }\end{array}$ & $\begin{array}{l}28 \\
13 \\
13 \\
13\end{array}$ & $\begin{array}{l}2 \cdot 0 \\
4 \cdot 85 \\
0 \cdot 25\end{array}$ & $\begin{array}{l}7217.8 \pm 291 \cdot 2^{*} \\
6329.1 \pm 367.0 \\
5072.7 \pm 733.4^{*} \\
4738.0 \pm 877.0^{*}\end{array}$ & $\begin{array}{c}100 \\
87 \cdot 6 \\
70 \cdot 2 \\
65 \cdot 6\end{array}$ \\
\hline Control untreated & 10 & & $2228.0 \pm 111.0$ & \\
\hline
\end{tabular}

${ }^{*} \mathrm{P}<0.01$.
Table 5 Depression of trypsinogen and chymotrypsinogen in homogenised pancreas of rats treated simultaneously with $5 \%$ bile solution and Antilysin

\begin{tabular}{|c|c|c|c|c|c|c|}
\hline \multirow[t]{2}{*}{ Drug } & \multirow{2}{*}{$\begin{array}{l}\text { Rats } \\
\text { (no.) }\end{array}$} & \multirow[t]{2}{*}{ Dose } & \multicolumn{2}{|l|}{ Trypsinogen } & \multicolumn{2}{|c|}{ Chymotrypsinogen } \\
\hline & & & (mg/g protein) & $(\%)$ & (mg/g protein) & $(\%)$ \\
\hline $\begin{array}{l}\text { Control } \\
\text { Antilysin }\end{array}$ & $\begin{array}{l}28 \\
13\end{array}$ & $\begin{array}{l}100000 \\
\text { KIU }\end{array}$ & $\begin{array}{r}17 \cdot 2 \pm 2 \cdot 5^{*} \\
6 \cdot 0 \pm 1 \cdot 2^{*}\end{array}$ & $\begin{array}{r}100 \\
34\end{array}$ & $\begin{array}{l}324.0 \pm 21.8 \dagger \\
240.0 \pm 19.4 \dagger\end{array}$ & $\begin{array}{r}100 \\
74\end{array}$ \\
\hline
\end{tabular}

$*_{P}<0.005 . \quad \dagger_{P}<0.01$.

some parts of the gastrointestinal tract (stomach, small intestine) (Cairnie et al., 1965) are organs with a high rate of turnover of proteins.

Cycloheximide is widely used as an inhibitor of protein synthesis in eukaryotes. It interferes with the synthesis of proteins on cytoplasmatic ribosomes (Baliga et al., 1969); however, care must be taken in interpreting its inhibitory effects (Timberlake and Griffin, 1974). After the administration of this antibiotic the activity of several enzymes was found to be enhanced (Čihák, 1975; Levine et al., 1975). 5-Azacytidine, successfully used in the treatment of acute leukaemia in childhood (Hrodek and Veselý, 1971), has a polyvalent inhibitory mechanism (Čihák, 1974). The drug is incorporated into different types of RNA, causes degradation of polyribosomes, and inhibits maturation of $45 \mathrm{~S}$ precursor ribosomal RNA (Čihák, 1975). As a result, inhibition of protein synthesis occurs (Reichman and Penman, 1973; Čihák, 1975), although the activity of several enzymes was also found to be increased after the use of this drug (Čihák et al., 1973; Čihák and Veselý, 1973). Cytembena, active in the treatment of gynaecological tumours (cf. Jandová et al., 1971), inhibits de novo purine biosynthesis (Slavíková et al., 1966). The drug causes a rapid and intensive inhibition of DNA biosynthesis (Jackson et al., 1975), and, at higher doses, inhibition of protein synthesis was observed (Veselá et al., 1970; Jackson et al., 1975).

Like 5-azacytidine, 5-fluorouracil interferes with the development of pancreatitis. Johnson et al. (1973) observed a favourable effect of 5-fluorouracil on the 
survival of dogs with experimental acute pancreatitis. The action of the analogue can also be explained, assuming that it interferes with the synthesis of nucleic acids (Wilkinson and Pitot, 1973) and proteins. In our earlier study, we observed (Korbová et al., 1974) that 5-azacytidine affects gastric secretion and depresses the secretion of hydrochloric acid. The administration of cycloheximide (Young et al., 1963) blocks the synthesis of proteins and results in a syndrome characterised by vomiting, diarrhoea, and progressive acidosis.

In the present study we used cytostatics, which do not inhibit protein synthesis immediately after their administration. However, their effect on experimental acute pancreatitis was observed in a shortterm experiment lasting six hours. Apart from the direct or indirect action of these compounds on the synthesis of proteins one has to take into consideration other possible mechanisms as well as the lessened gastric secretion resulting in the lower release of secretin and pancreozymin in the duodenum. It is possible that there is an alteration in the response of the exocrine pancreas to the changed diet (Lavau et al., 1974) caused by a blocked dietary absorption in cycloheximide or 5-azacytidine-treated animals (Korbová et al., 1974). Also the secretion of digestive enzymes from the pancreas (Rothman and Isenman, 1974) can be impaired by the action of these drugs.

At present it is difficult to explain how cycloheximide, 5-azacytidine, or Cytembena actually affect experimental acute pancreatitis induced by interstitial administration of bile solution and prevent the autodigestion of the pancreas. Cycloheximide, which is relatively non-toxic (Young and Dowling, 1975), was active in our experiments at low doses thus permitting its possible clinical use.

\section{References}

Backwinkel, K.-P., Schriewer, H., Rauen, H. M., and Themann, H. (1975). Ultrastrukturelle Aspekte zur Pathogenese der Desoxycholat-Pankreatitis. (English abstract.) Research in Experimental Medicine, 166, 43-52.

Baden, H., Jordal, K., Lund, F., and Zachariae, F. (1969). Prophylactic and curative action of Trasylol in pancreatitis. A double-blind trial. Scandinavian Journal of Gastroenterology, 4, 291-295.

Baliga, B. S., Pronczuk, A. W., and Munro, H. N. (1969). Mechanism of cycloheximide inhibition of protein synthesis in a cellfree system prepared from rat liver. Journal of Biological Chemistry, 244, 4480-4489.

Bawnik, J. B., Orda, R., and Wiznitzer, T. (1974). Acute necrotizing pancreatitis. American Journal of Digestive Diseases, 19, 1143-1147.

Beck, I. T., Kahn, D. S., Solymar, J., McKenna, R. D., and Zylberszac, B. (1964). The role of pancreatic enzymes in the pathogenesis of acute pancreatitis. III. Comparison of the pathologic and biochemical changes in the canine pancreas to intraductal injection with bile and with trypsin. Gastroenterology, 46, 531-542.

Beck, I. T., McKenna, R. D., Zylberszac, B., Solymar, J., and Eisenstein, S. (1965). The effect of a trypsin inhibitor, Trasylol, on the course of bile and trypsin-induced pancreatitis in dogs. Gastroenterology, 48, 478-483.

Becker, V. (1973). Bauchspeicheldrüse Inselapparat ausgenommen (Spezielle pathologische Anatomie. Vol. 6). Springer-Verlag: Berlin.

Cairnie, A. B., Lamerton, L. F., and Steel, G. G. (1965). Cell proliferation studies in the intestinal epithelium of the rat. I. Determination of the kinetic parameters. Experimental Cell Research, 39, 528-538.

Carey, L. C. (1973. The Pancreas. C. V. Mosby: Saint Louis. Čihák, A. (1974). Biological effects of 5-azacytidine in eukaryotes. A review. Oncology, 30, 405-422.

Čihák, A. (1975). Character of the stimulatory response of uridine kinase in rat livers to cycloheximide treatment. European Journal of Biochemistry, 58, 3-7.

Čihák, A., Lamar, C., and Pitot, H. C. (1973). Studies on the mechanism of the stimulation of tyrosine amino transferase activity in vivo by pyrimidine analogs: the role of enzyme synthesis and degradation. Archives of Biochemistry and Biophysics, 156, 176-187.

Čihák, A., and Veselý, J. (1973). Enhanced uridine kinase in rat liver following 5-azacytidine administration. Journal of Biological Chemistry, 248, 1307-1313.

Cohen, A., and Kulka, R. G. (1974). Induction of chymotrypsinogen by hydrocortisone in embryonic chick pancreas in vitro. Journal of Biological Chemistry, 249, 45224527.

Creutzfeldt, W., and Schmidt, H. (1970). Aetiology and pathogenesis of pancreatitis. Scandinavian Journal of Gastroenterology, Suppl. 6, 47-62.

Edlund, Y. (1970). The etiology and pathogenesis of acute pancreatitis. Schweizerische Medizinische Wochenschrift, 100, 1174-1178.

Elliott, D. W., Williams, R. D., and Stewart, W. R. C. (1958). The role of trypsin and bile salts in the pathogenesis of acute pancreatitis. Surgical Forum, 9, 533-537.

Hrodek, O., and Veselý, J. (1971). 5-Azacytidine in childhood leukemia. Neoplasma, 18, 493-503.

Jackson, R. C., Taylor, G. A., and Harrap, K. R. (1975). Aspects of the biochemical pharmacology of Cytembena. Neoplasma, 22, 259-268.

Jandová, A., Škoda, V., Novotná, J., Pezlarová, J., and Pick, P. (1971). Short-term administration of Cytembena and cyclophosphamide to patients with gynaecological carcinoma. Neoplasma, 18, 197-218.

Johnson, R. M., Barone, R. M., Newson, B. L., Das Gupta, T. K., and Nyhus, L. M. (1973). Treatment of experimental acute pancreatitis with 5-fluorouracil (5-FU). American Journal of Surgery, 125, 211-221.

Keith, L. M., Barnes, J. E., and Denkewalter, F. R. (1958). Experimental study of interstitial injection of trypsin and trypsinogen into the pancreas. Archives of Surgery, 77, 416-420.

Korbová, L., Kohout, J., and Čihák, A. (1974). Impaired gastric secretion in rats treated with 5-azacytidine. Archives Internationales de Pharmacodynamie et de Thérapie, 209, 332-341.

Lavau, M., Bazin, R., and Herzog, J. (1974). Comparative effects of oral and parenteral feeding on pancreatic enzymes in the rat. Journal of Nutrition, 104, 1432-1437.

Levine, J. H., Nicholson, W. E., and Orth, D. N. (1975). Nature of the increase in renal ornithine decarboxylase activity after cycloheximide administration in the rat. Proceedings of the National Academy of Sciences of the United States of America, 72, 2279-2283.

Lombardi, B., Estes, L. W., and Longnecker, D. S. (1975). Acute hemorrhagic pancreatitis (massive necrosis) with fat necrosis induced in mice by DL-ethionine fed with a choline-deficient diet. American Journal of Pathology, 79, 
$465-475$.

Lowry, O. H., Rosebrough, N. J., Farr, A. L., and Randall, R. J. (1951). Protein measurement with the Folin phenol reagent. Journal of Biological Chemistry, 193, 265-276.

Mališ, F., Frič, P., and Slezák, Z. (1972). Srovnání účinku proteinázových inhibitorú Antilysinu, Contrykalu a Trasylolu na trypsinovou a chymotrypsinovou aktivitu člověka. Československá Gastroenterologie a výživa, 26, 12-17.

Malis, F., Kasafïrek, E., Frič, P., and Josífko, M. (1974). Application of the new synthetic substrates N-a-tosyl-Larginine-p-nitroanilide and $\mathrm{N}$-a-benzyloxy-carbonyl- $\mathrm{L}$ arginine-p-nitroanilide in the determination of trypsin activity in the duodenal contents. Zeitschrift für Klinische Chemie und Klinische Biochemie, 12, 494-497.

Mansfeld, V., Rybák, M., Horáková, Z., and Hladovec, J. (1960). Die antitryptische, antifibrinolytische und antiphlogistische Aktivität natürlicher Proteasen-Inhibitoren. Hoppe-Seyler's Zeitschrift für Physiologische Chemie, 318, 6-11.

Novi, A. M., Blackburn, A., Woo, J., and Baserga, R. (1973). Increase in chromatin template activity induced by cycloheximide. Laboratory Investigation, 29, 714-722.

Nugent, F. W., and Atendido, W. A. (1965). The role of antienzymes in the treatment of acute pancreatitis. American Journal of Gastroenterology, 43, 437-442.

Palmer, E. D. (1975). Practical Points in Gastroenterology, 2nd edition. Hans Huber Publishers: Berne; Kimpton: London.

Raderecht, H. J. (1959). Zur Bestimmung der Serumlipase. I. Bestimmung mit Phenyllaurat als Substrat. Clinica Chimica Acta, 4, 221-226.

Reichman, M., and Penman, S. (1973). The mechanism of inhibition of protein synthesis by 5-azacytidine in HeLa cells. Biochimica et Biophysica Acta, 324, 282-289.

Rothman, S. S., and Isenman, L. D. (1974). Secretion of digestive enzyme derived from two parallel intracellular pools. American Journal of Physiology, 226, 1082-1087.

Schiller, W. R., Suriyapa, C., and Anderson, M. C. (1974). A review of experimental pancreatitis. Journal of Surgical Research, 16, 69-90.
Slavíková, V., Semonský, M., Slavík, K., Zikán, V., Bloch, A., and Veselá, H. (1971). Contribution to elucidation of biochemical action mechanism of Cytembena. Neoplasma, 18, 455-457.

Slavíková, V., Semonský, M., Slavík, K., and Volejníková, J. (1966). Inhibition of purine biosynthesis and of tetrahydrofolic acid formylase by $\beta$-4-methoxybenzoyl- $\beta$ bromoacrylic acid. Biochemical Pharmacology, 15, 763-768.

Teller, J. D. (1950). Measurement of amylase activity. Journal of Biological Chemistry, 185, 701-704.

Timberlake, W. E., and Griffin, D. H. (1974). Differential effects of cycloheximide and other inhibitors of protein synthesis on in vivo ribosomal RNA synthesis in Achlya bisexualis. Biochimica et Biophysica Acta, 353, 248-252.

Veselá, H., Kraus, P., Semonský, M., and Slavíková, V. (1970). The influence of MBBA on incorporation of some amino-acids in the proteins of Yoshida ascites rat sarcoma cells. Neoplasma, 17, 49-52.

Walther, B. T., Pictet, R. L., David, J. D., and Rutter, W. J. (1974). On the mechanism of 5-bromodeoxyuridine inhibition of exocrine pancreas differentiation. Journal of Biological Chemistry, 249, 1953-1964.

Waterman, N. G., Walsky, R., Moore, R., and Howell, R. S. (1969). Acute pancreatitis: an experimental model. Surgery, 66, 746-750.

White, T. T., and Allan, B. J. (1974). Intrapancreatic activation of proteases in the etiology of pancreatitis and cancer of the pancreas. Medical Clinics of North America, 58, $1305-1310$.

Wilkinson, D. S., and Pitot, H. C. (1973). Inhibition of ribosomal ribonucleic acid maturation in Novikoff hepatoma cells by 5-fluorouracil and 5-fluorouridine. Journal of Biological Chemistry, 248, 63-68.

Young, C. W., and Dowling. M. D. (1975). Antipyretic effect of cycloheximide, an inhibitor of protein synthesis, in patients with Hodgkin's disease or other malignant neoplasms. Cancer Research, 35, 1218-1224.

Young, C. W., Robinson, P. F., and Sacktor, B. (1963). Inhibition of the synthesis of r rotein in intact animals by acetoxycycloheximide and a metabolic derangement concomitant with this blockade. Biochemical Pharmacology, $12,855-865$. 